\title{
Initiatives to Regulate the Legal Situation of Jewish Communities in Galicia in the Second Half of the Nineteenth Century: Greater Autonomy for Communities, or Increased Dependence on the Secular/State Administration? ${ }^{1}$
}

\author{
Hanna Kozińska-Witt \\ (Independent scholar) \\ e-mail: kozinska@web.de
}

Key words: equal rights, liberal reform, regional laws, status of Jewish community, Jewish community statute, law of 21 March 1890

\begin{abstract}
The article discusses the process of the introduction in Galicia of a new law regulating the relations between Jewish communities and the authorities of the territorial administration. Unlike in the Galician provinces, where the Josephine patent of 1789 continued to be applied, certain Jewish communities in the cities here had developed new statutes previously, leading to partial changes in the elections for community councils. The first was the Krakow community (1870), whose Orthodox rabbi Szymon Schreiber (Sofer) attempted to withdraw the implemented changes, designing his own version of the new statutes (1882). The struggle over the form of the new law ultimately culminated with the Viennese government's issue of relevant regulations in 1890 .
\end{abstract}

\section{The complicated starting point}

The "December constitution", dating to 21 December 1867, gave equal rights to individual Jews. ${ }^{2}$ The relations between political and religious communities were regulated in broad strokes by the community law of 12 August 1866. The law awarded every religious community the right to organise and administer its own internal affairs, as well

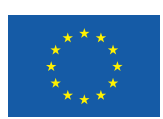

${ }^{1}$ This article was written for project no. 2015/19/P/HS3/04054 in programme Polonez 1 organised by National Science Centre which received funding from the European Union's Horizon 2020 research and innovation programme under Marie Skłodowska-Curie grant agreement no. 665778. Logo EU https://europa.eu/european-union/about-eu/symbols/flag_en.

${ }^{2}$ Herrnritt 1905: 974-981, here: 974. On Herrnritt see: http://www.biographien.ac.at/oebl/oebl_H/Herrmann-Herrnritt_Rudolf_1865_1945.xml (Accessed: 12 April 2018); "Gminne sprawy", in: Kasparek 1873, vol. III, 1589-1590; "VI o zawiadowaniu specyalnymi sprawami ludności chrześcijańskie i izraelickiej", $\S 89-\S 97$, in: Kasparek 1884, vol. 1: 47-49. 
as to possess and use its own establishments, institutions and funds for religious, teaching and charitable purposes.

As Majer Bałaban wrote, however, "the state constitutional laws did not immediately abolish the regional laws". ${ }^{3}$ It is therefore rather surprising to note that, in the first edition of the canonical "Compendium of Administrative Legislation" (1868), Jan Rudolf Kasparek continued to quote the text of the Josephine patent from $1789 .{ }^{4}$ Kasparek's reason for this was that the Josephine system was still de facto binding in Galicia. ${ }^{5}$ No law had been passed to regulate the "external relations of the religious association of adherents of the Jewish religion", resulting in legal chaos and the "absence" of state authority as well as civil law in religious communities. ${ }^{6}$ Philip Friedman goes as far as to speak of anarchy reigning in the majority of communities, as a result of the lack of a legal basis to regulate their administration. ${ }^{7}$ Only a few of the Jewish communities in Galicia, including those in Krakow and Lwów (L'viv) produced their own statutes, ${ }^{8}$ and were thus able to administer internal community affairs in a modernised fashion. Many Jewish communities remained unorganised and eluded any control, and according to the statements of the general administration, their authorities were supposedly tyrannising the Jews under their jurisdiction. Legislative changes were proposed: "If equal rights are to be realised and not an illusion, then in no terms may exceptional regulations exist for the Jewish population". ${ }^{9}$

The reform of the legal status of the Jewish communities appeared to be complicated to implement, however, and was not regarded as a priority. ${ }^{10}$ Other areas attracted greater interest, including building roads, de-privatisation of the railways, river regulation, assistance to the victims of crop failure, and finally the indemnity law. Teofil Merunowicz, a regional assembly deputy, said that: "The previous government [...] was opposed to any raising of the Jewish question in whichever form". ${ }^{11}$ According to Merunowicz, government action was confined to an enigmatic confidential memorandum to the starosties of 28 June 1875, stating: "The hypothecation laws have allowed Jews to achieve religious equality, but they have not been exempted from the obligations to which the adherents of all other religions are subject, even the one that was

${ }^{3}$ Bałaban 1909: 26.

4 “IV. Patent zawierający ustawę gminą ludności izraelickiej w Galicyi z dnia 7 maja 1789”, in: Kasparek 1868, vol. 1: 97-112. Jan Rudolf Kasparek (1824-1890) was a jurist and starosta in Chrzanów. On the Josephine patent Pacholkiv 2014: 111-118.

${ }^{5}$ Friedman 1929: 145; Żbikowski 1995: 111, note 1; Dziadzio 2001: $237 \mathrm{f}$.

6 "Multiple inconsistencies with the laws that later came into force. From time to time a differing resolution in Jewish matters, which are conflicting and represent an indescribable chaos. E.g. the resolution on the Jewish domestic tax from 22 July 1833, 1. 26418, thereafter resolutions concerning diverse specifically Jewish community issues: from 18 February 1869 1. 5979, from January 1872 L. 13047, from 1 October 1868 1. 6754 and 14 September 1870 1. 8671 etc.", in: Sprawozdanie stenograficzne z rozpraw galicyjskiego Sejmu krajowego 1882: 67-68.

${ }^{7}$ Friedman 1929, p. 144f.; “Korespondencja Czasu. Wiedeń”, Czas 12 Febuary 1888, no. 35: 1.

${ }^{8}$ On Kraków's and Lwów statutes see below. The whole lists of statutes is a desideratum. Jewish communities that published statute before 1890s were for example Przemyśl, Stryj, Andrychów, Grzymałów, Peczeniżyn. Thanks to dr Alicja Maślak-Maciejewska for this information.

${ }^{9}$ Sprawozdanie stenograficzne z rozpraw galicyjskiego Sejmu krajowego 1882: 63; Merunowicz 1879: $215 f$.

${ }^{10}$ Editorial, Czas, Kraków 1879, in: Żbikowski 1994: 22-25.

${ }^{11}$ Sprawozdanie stenograficzne z rozpraw galicyjskiego Sejmu krajowego 1882: 63. 
formerly dominant - because public order, and thus also the good of the state, require that they be satisfied". ${ }^{12}$

On 30 March 1876, on the initiative of ministerial adviser Edward Gniewosz, at least in theory the traditional kahals were dissolved, with the intention of bringing order to Jewish community affairs. ${ }^{13}$ It was, however, unclear how to introduce the essential reforms without also "inciting the Semitic question". ${ }^{14}$ Unfortunately, there was no explanation for how this question was defined at the time. One can only assume that it was feared that Jews with equal rights would dominate the "passive" social classes, which would defend themselves by using violence, provoking anti-Jewish disorder and destroying the previous social order.

Reform of the legal position of Jewish people became a cause engaging liberal Jewish politicians in the Diet of Galicia and Lodomeria - the regional assembly - and the parliament in Vienna. Paradoxically, one of the most visible politicians active in this issue was the aforementioned anti-Semite, Teofil Merunowicz (1846-1919). ${ }^{15}$

\section{The activity of Teofil Merunowicz}

In 1893 Merunowicz wrote in summary of his many years of work:

Fifteen years ago, I began to agitate in this direction in order to bring the government and legislative authorities to undertake careful examination of the legal situation of Jews and to provide clear regulation of their relationship with the general population and the state according to the principles of equality and justice. In writing, in print, in petitions to the Diet, to the Polish Club in Vienna, to the Imperial Council and to the emperor, and finally, when elected to the Diet, by means of deputies' motions, I attempted to point to the need for able assessment of the nature of the internal religious-national organisation of Jews, in order to make it possible, without unnecessarily infringing on Jewish customs and religious arrangements that are harmless to other sections of the population, to effectively counteract their institutions and customs which are harmful for the Christian population, or give the Jews an exceptional position, to the detriment of the non-Jewish population. ${ }^{16}$

Merunowicz's petition to the Vienna Imperial Council of 31 October 1879 brought him renown. ${ }^{17}$ Despite its rejection by the so-called Polish Club, it was submitted to the Chamber of Deputies by Ignacy Kamiński, a deputy who sympathised with

${ }^{12} \mathrm{Ibid}$. Which obligations were meant? Certainly not military service. On military service and the Jews see Fryling 1883: 6 n.

${ }^{13}$ Rosenfeld 1918: 250; Bałaban 1909: 27f. Elsewhere, Bałaban mentions Gniewosz's initiative in 1874, Bałaban 1907: 34; Semczyszyn 2014: 214.

${ }^{14}$ [no title] Czas 11. October 1882, no. 232: 1f., here 2.

${ }^{15}$ Żbikowski 1995: 58 (note 3), 59. Zdrada, Jerzy: “Teofil Merunowicz”, at: http://www.ipsb.nina.gov. pl/a/biografia/teofil-merunowicz (Accessed: 20 April 2018).

${ }^{16}$ Merunowicz 1893: 81.

${ }^{17}$ Żbikowski 1994: 23; Moszczyński 2017: 106. 
Merunowicz. ${ }^{18}$ The petition comprised three points. ${ }^{19}$ The first demanded the regulation of religious affairs, in the same ways as had occurred with the Catholic Church. In the second point, Merunowicz called for "Israelite priests" to be required to have an appropriate education and maintain civic conduct. In the third, he demanded a state-sanctioned translation of the Talmud and studies explaining what these "mysterious Jewish books" actually contained.

Merunowicz's petition was rejected, and he continued to operate at a local level as an opinion writer, journalist for Gazeta Narodowa daily, and deputy to the Diet.

Until the end of his life, the reform of the status of Jewish communities, interlaced with the belief in the harmful nature of Jews and the terrible power of the Talmud, remained one of the prominent features of Merunowicz's work. ${ }^{20}$ In September 1881 he submitted a further petition in three points to the Diet. ${ }^{21}$ This time he called for: 1 . Examination of all the laws regulating the situation of Jews and an explanation of why the situation of the Jews throughout Austria differed from that of the rest of the population; he demanded the award of a credit amounting to 10,000 gulden for organising a conference and enabling the work of specialists - Hebraists and lawyers - to explain the mysteries of the Talmud; 2. Checks on the keeping of Jewish registers; 3. Development of effective checks on conscription books; and 4. Introduction of statutory credit regulation.

Merunowicz's petition was also commented on in Krakow. We have information on the position of the Cracovian elites towards his activity in the form of a comment from one of the founders of the Krakow periodical Czas, Paweł Popiel. ${ }^{22}$ The same author presented his views more widely in subsequent issues of $\mathrm{Czas}$ from $1881 .{ }^{23} \mathrm{He}$ noted that the Jewish population occupied a separate and privileged position in Galician society, one manifested in a monopoly on trade and industry, as well as powerful influences on social life. This privilege could provoke "agitation" in lower social strata that might threaten the social order. However, he saw scientific research on mysterious Jewish institutions as unnecessary, and he regarded the cause of the problem as the "caste spirit", the material and economic struggle, and the struggle of "individuals with the monopolising [Jewish] crowds". According to Popiel, Jews accumulated and monopolised the benefits of equal rights, and responsible for this were both Europe's general economic

${ }^{18}$ Ignacy Kamiński (1819-1902) was the mayor of Stanisławów (now Ivano-Frankivsk). In 1883 he was elected to the Vienna parliament thanks to the support of Orthodox Jews; Semczyszyn 2014: 215. Merunowicz was criticised in Czas by Jonatan Warschauer, Czas 176, 274 (1879).

19 "Kleine Chronik, Lemberg", Neuzeit 5 December 1879, no. 49: 3.

${ }^{20}$ According to Maciej Moszyński, Merunowicz "combined elements of anti-emancipatory rhetoric with conspiracy theory, based on fears over the pernicious role of the Talmud and the kahal system", Moszyński 2017: 106; similarly Żbikowski 1995: 136.

21 “Z Sejmu. 8-me posiedzenie d. 28go września, Wniosek Merunowicza”, Czas 30 September 1881, no. 223: 2; "Korespondencya 'Czasu'”, Czas 29 October 1881, no. 248: 1; Feldman 1907: 276.

22 Paweł Popiel (1807-1892), in: Kieniewicz Stefan: Popiel, Paweł, at: http:/www.ipsb.nina.gov.pl/a/ biografia/pawel-popiel (Accessed: 11 April 2018).

23 "Korespondencya 'Czasu", Czas 29 October 1881, no. 248: 1; "Czas, which graciously proclaims the principle of 'tolerance' towards Jews, of course cannot contribute to the concept of equal rights [...]”, in: Feldman 1894: 51. 
principles and the specific role of Alliance Israélite. ${ }^{24}$ He argued that the Josephine patent privileged only the Jews, while also subjecting the Catholic Church to secular rule.

This statement shows that the "first generation of conservatives", represented here by Paweł Popiel, had a view of the activities of Jews in Galician society similar to that of Merunowicz. ${ }^{25}$ The supporters of the status quo and traditional hierarchies saw "equal rights" as meaning "privileges" for a social group that would be able to exploit them in order to damage other, less active classes. The Warsaw publication Izraelita wrote of this position that, according to those who favoured it, Jews did not have "equal rights", but rather "extra rights". ${ }^{26}$ Conservatives continued to back the ideas of pre-modern religious tolerance, and they opposed the combination of the issue of dangerous "privileging" with the religious question. They tended to view the threats as stemming from the socio-economic situation, rather than Talmudic "Jewish mysteries".

The Diet administrative committee sent Merunowicz's petition for clearing to the Regional Government. ${ }^{27}$ The government was to ascertain whether, apart from the Josephine patent of 1789, any other exceptional laws, regulations or decrees applied to Jews, as well as which of those specific resolutions of the patent giving Jews a separate community system had been repealed by subsequent state or regional laws and which were still binding, and finally what actions needed to be taken as a result. As was often the case with other motions, on this occasion the committee's proposal also got stuck somewhere in a government drawer. This did not, however, put Merunowicz off taking further steps in the same direction.

In 1882 Merunowicz presented two proposals, one of which to a certain degree reopened the previous petitions concerning the "Jewish question":

The Assembly calls upon the Government for the third time to carefully examine all laws, regulations and decrees concerning the Israelite population, and in the appropriate way, to endeavour to regulate thoroughly the legal relations of the Mosaic faith in terms of the constitutional entitlement with the population of other religions. ${ }^{28}$

According to Czas, the wording of the motion proposed in 1882 was blunter and more irascible than that of the previous year (28 September). ${ }^{29}$ The cause of this was the anti-Jewish mood that prevailed in 1882: the first anti-Semitic congress had just been held in Dresden, while the Galician Jewish camp itself had experienced heightened conflicts associated with the organisation of a rabbinical convention and the statutory initiative of the Krakow rabbi and leader of Galician Orthodox Judaism Szymon Schreiber

\footnotetext{
${ }^{24}$ Alliance Israélite Universelle, an international organisatiton founded in Paris in 1860 with the aim of defending Jews' rights, see at http://www.jewishvirtuallibrary.org/alliance-israelite-universelle (Accessed: 1 June 2018).

${ }^{25}$ On the views of the circles surrounding Czas, see Żbikowski 1995: 270-277, 281f., 285.

${ }^{26}$ Quoted in Moszyński 20017, p. 106, note 141; on the anti-Jewish position of the group connected to Czas, see Friedman 1929: 164f.

27 “Korespondencya 'Czasu”, Czas 29 October 1881, no. 248: 1.

${ }^{28}$ Merunowicz's motion in "Sprawozdanie sejmowe”, Czas 13 September 1882, no. 208: 1; "Telegramy własne Czasu. Sejm”, Czas 15 September 1882, no. 210: 3; "Sejm sprawozdanie sejmowe”, Czas, 16 September 1882: 1-2; "Kleine Chronik, Wien”, Neuzeit 22 September 1882, no. 38: 319f.; Rosenfeld 1918: 250.

29 "Korespondencja Czasu”, Czas 16 September 1882, no. 211: 2; "Z Sejmu. 8-me posiedzenie d. 28go września, Wniosek Merunowicza”, Czas 30 September 1881, no. 223: 2.
} 
(see below). Czas was firmly opposed to linking the alleged ritual murder in Lutcza (the Ritter case) $)^{30}$ with the matter of the legal regulations of Jewish communities.

A different position from that of the conservatives was represented by the liberal Reforma. The author of its titular article from 5 October 1882 opposed the demonization and exaggeration of the terrible role of Jews in society. He argued that if:

[...] kahals have any rights and privileges that go beyond the religious sphere, stretch to administrative affairs, and give kahals a different position from the religious authorities of other religions, these sole privileges should be removed. If Jews' keeping of registers, despite the rather firm decrees issued several years ago, continues to be inadequate, single record books of civil status should be introduced $[\ldots] .^{31}$

The newspaper called for the Polonization of Jews through education and the establishment of societies, companies and savings banks for the Christian population.

\section{Merunowicz's views and the contents of the petitions}

Guided by the observation that "the Jews cannot be grasped by the law (a folk saying)", and resorting to conspiracy theories to interpret the situation, Merunowicz called for the reform of kahals. ${ }^{32}$ In 1879 he complained that the community law treated all religions equally only in theory, as on 7 May 1874 (National Law Register no. 50), a separate law had been enacted according to which de facto all administrative cases of the Catholic Church were left in the jurisdiction of secular political offices, while Jewish communities continued to be autonomous. ${ }^{33} \mathrm{He}$ argued that there was imprecise designation of the boundaries between the religious importance of the Jewish community and its administrative importance, i.e. administration of the funds of kahals, establishments, foundations and stipends, imposing supplements on taxes and other contributions for the members of Jewish religious communities, supervision of the administrative affairs of Jewish communities, and court proceedings in disputes resulting from these conditions. ${ }^{34} \mathrm{He}$ demanded abrogation of the kahals' right to execute those legal and administrative functions that exceeded this limit.

According to Merunowicz, the continued existence of the institution of Jewish communities was contrary to the principles of equal rights, since they provided Jews with an exceptional and beneficial position, to the detriment of other citizens. ${ }^{35}$ The kahals themselves were disorderly, and yet constituted a state within a state.

${ }^{30}$ Cieśla/Żyndul 2004: 439-451.

31 "Kraków, 5 października", Reforma 6 October 1882: 1.

${ }^{32}$ Merunowicz 1876: 104.

${ }^{33}$ Merunowicz 1879: 76. The law of 7 May 1874, RGBL 50/1874, divided cases into internal Church ones, where state intervention was disallowed, and those of external Church relations, in which the state could intervene; Dziadzio 2001: 234-237.

${ }^{34}$ Merunowicz 1879, p. $217 \mathrm{f}$.

35 “Z Sejmu", Czas 4 October 1881, no. 226: 2; [Popiel, Paweł?] [no title], Czas 6 October 1881, no. 228: $1-2$. 
In Andrzej Żbikowski's view, the anti-kahal campaign that Merunowicz launched in the late 1870 s remained only a marginal issue in Galicia's political life, since there was little interest in this question, with a preference for leaving decisions up to Vienna. ${ }^{36}$ The Diet's position was presented in October 1882 by the rapporteur Franciszek Wolfart in response to Merunowicz's petition in the matter of regulating the legal relations of the Israelite population. ${ }^{37}$ The members of the Regional Government admitted that they did not know how the legal situation of Jewish communities looked, but suspected that they continued to be administered by obsolete laws. They demanded that the Regional Government officially account for the way in which the legal relations of the Jewish population in Galicia were actually regulated.

\section{Jewish liberals}

In 1879 Merunowicz mentioned a pamphlet of the "Schomer Israel" association aimed against him, yet granting him moderation and calmness of arguments. ${ }^{38}$ Schomer Israel was active in Eastern Galicia, and was initially a pro-centralist association of Germanised Jewish liberals, who, while continuing to be liberals, had adopted pro-Polish positions in the 1880s. Since 1869, the association had been publishing the newspaper Der Israelit. ${ }^{39}$ These circles attributed to Merunowicz support for endeavours to legally regulate the situation of Jewish communities. This is demonstrated by the regional assembly debates in 1882 and the election campaign for the Vienna parliament in 1883. They came right in the middle of a fierce dispute between Progressive Jews [postepowcy], calling for the reform of religious communities in Galicia, and their Orthodox counterparts congregated in the Machsike ha-Dat association, with Rabbi Schreiber at the helm, who were interested in keeping the communities broadly autonomous, and expressed their views in the Machsike ha-Dat publication (from 1879). ${ }^{40}$ This organisation, whose critics dubbed the "Anti-Schomer", ${ }^{41}$ was founded with the support of the very influential Hasidic tsaddik from Belz, Yehoshua Rokeach (1825-1894), ${ }^{42}$ and it assumed decidedly anti-liberal and traditionalist positions.

Supporting Merunowicz's demands for reform of the communities, liberal deputies Dr Filip Zucker, Dr Bernard Goldman and Dr Filip Fruchtman criticised his

\footnotetext{
${ }^{36}$ Żbikowski 1995: 59 note 3.

37 “Sejm galicyjski”, Reforma 12 October 1882, no. 233: 2; Merunowicz's motion in "Sprawozdanie sejmowe”, Czas 13 September 1882, no. 208: 1; "Telegramy własne Czasu. Sejm”, Czas 11 October 1882, no. 232: 3; "Sejm sprawozdanie sejmowe”, Czas 12 October 1882, no. 233: 2.

38 "Sejm sprawozdanie sejmowe", Czas, 16 September 1882, no. 211: 1-2.

${ }^{39}$ Aleksiun, Natalia: Schomer Israel, in: http://www.jhi.pl/psj/Szomer_(Schomer)_Israel (Accessed: 5 April 2018); on Der Israelit see Feldman 1894: 10f.

${ }^{40}$ Manekin Rachel: "Makhzikey ha-Das", at: http://www.yivoencyclopedia.org/article.aspx/Makhzikey_ ha-Das (Accessed: 1 February 2018); Feldman 1894: 11; Semczyszyn 2014: 214.

41 "Antischomer", in: "Kleine Chronik, Lemberg", Neuzeit 11 April 1879, no. 14: 116; "Der jüdische Kulturkampf in Galizien”, Neuzeit 18 April 1879, no. 16, 121.

${ }^{42}$ On the dynasty of the Belz Hasidic dynasty, see Assaf, David: http://www.yivoencyclopedia.org/article.aspx/Belz_Hasidic_Dynasty (Accessed: 5 April 2018). According to Bałaban, "Belz tsaddik [became] a synonym of the strength of Hasidism [...]", Bałaban 1916: 190.
} 
anti-Semitism as well as his belief in conspiracy theories and the negative influence of the Talmud. ${ }^{43}$ Zucker, Merunowicz's most distinguished opponent, published his speech to the Diet as a separate pamphlet. ${ }^{44} \mathrm{He}$ immediately stated that he agreed with Merunowicz's suggestion regarding the need to regulate the legal status of Jewish communities. But he then stressed that Merunowicz's belief that the Josephine patent and later legal regulations gave Jews a distinct and exceptional position was incorrect. As early as 1785, the administrative-judicial attributions of religious communities were rescinded, and their members were made subject to the regional laws, and Jews to local authority. The kahals only retained their religious functions. Zucker accused Merunowicz of failure to present evidence to support his accusations concerning the legal separatism of Jews and the ruler of kahals. ${ }^{45}$ "Indeed, Mr Merunowicz presents a sad horoscope to Jews, by characterising them in an unfavourable manner, and appearing to regard the civic path as closed to them". ${ }^{46}$

On what basis, asked Zucker, did Merunowicz claim that the Josephine patent gave Jews a separate position? ${ }^{47}$ The kahals had been stripped of their special rights regarding collection of taxes and establishing military contingents. Initially they retained the right to maintain population records and keep registry books, but this too was removed, leaving only the right to issue certificates of morality and poverty, which needed to be confirmed with the administrative authorities. According to Zucker, this made the kahals' attributions comparable to those enjoyed by the parishes of other religions. He also argued that rabbinical courts decided only in matters of a religious nature, since in other matters Jews attended civil courts. ${ }^{48}$ Zucker pointed to the rush of Jews to secular schools, as well as the lack of suitably educated teachers of Judaism and gaps in the education of rabbis. ${ }^{49}$

Zucker's question to Merunowicz was in fact never answered. Perhaps the latter was deviously and accusingly noting that the law remained "on paper"? In any case, the constitution and later laws changed, at least theoretically, the legal situation of Jews and religious communities, but the declaration of equal rights did not automatically mean that the provincial Jewish communities were affected by the modern law. As a result, they remained "opaque" for the administrative authorities, and therefore mysterious in a negative sense. This did not apply to the communities in Krakow and L'viv, however, which modernised their administration system.

${ }^{43}$ Bałaban 1909: 27; Fryling 1883: 12. The name is spelt Zucker or Zuker.

${ }^{44}$ Zuker 1882.

${ }^{45}$ Ibid.: 16.

${ }^{46}$ Ibid: : 27.

${ }^{47}$ Ibid.: 5 . The principle of rabbis keeping record books was scrapped by the decree of the imperial and royal Minister of Internal Affairs of 15 March 1875, Lewandowska 1995: 63-76, here: 65.

${ }^{48}$ Zuker 1882: 9f.

${ }^{49}$ Ibid.: $12 \mathrm{f}$. and $14 \mathrm{f}$. 


\section{Liberal statutes: the Krakow Statute}

Liberal Jewish circles elaborated liberal statutes for the religious communities in Krakow (first published in 1870) ${ }^{50}$ and L'viv (first published in 1878).$^{51}$ It is interesting that these legal acts are not mentioned by Philip Friedman in his pioneering book, which states only that 78 Jewish communities in Galicia had statutes approved by the authorities, including 58 in Bohemia and two in Bukovina. ${ }^{52}$ I was unable to find out which might have been the model for the Krakow and L'viv communities.

In the transitional period in Krakow (1866-1870), isolated voices appeared suggesting that confessional communities did not need any statutes at all, since they were subject to the local municipal government, which should be responsible for their administration. ${ }^{53}$ However, complete dependence on the municipal authorities was not in accordance with the intentions of the majority of Jews, and as a result a statute was elaborated to satisfy the specific needs of followers and maintain the community's autonomy.

The Krakow statute defined a Jewish community as a religious, not political group, grouping all the adherents of the religion permanently living in its area $(\S 1)$. The community's objective was to cater for the religious needs of its members and to support its religious, scientific and charitable institutions and interests $(\S 3)$. The community was obliged to keep registers - both of persons and inventories $(\S 4)$ - and its members undertook to support its endeavours intellectually and financially $(\S 6)$.

The congregation was to be administered by a council comprising six senior members, including a president and vice-president, and 24 councillors, all unpaid ( $§ 8)$. The right to vote was decided by personal and material attributes $(\S 9)$. The personal ones included: male sex, age of not less than 24 years, Austrian citizenship, permanent residence in the community for at least three years, financial independence, and one of the following characteristics:

Academic status; independent practice of vocation, be it clerical, skilled or artistic; character and rank of an imperial and royal officer or member of permanent staff (militia stabilis), or settled and pensioned here; rank and character of a state, regional or district official, either active or pensioned; payment of permanent taxes for the Israelite congregation, or in the case of a permanent state tax at least in the amount of 5 Austrian gulden annually, not counting additions. ${ }^{54}$

\footnotetext{
${ }^{50}$ Statut dla Zboru izraelickiego w Krakowie 1870; Żbikowski 1995: 111-113.

${ }^{51}$ The statute was in reconstruction and not available to me. My thanks to Dr Maria Vovchko for this information. Dr Vovchko tracked down a number of draft statutes which were not approved. This would indicate that discussions on the shape of statutes took place very intensively in L'viv. Manekin refers to statutes forced through in 1876 by Schomer Israel, Manekin 2011: 165-198, here: 175.

${ }^{52}$ Friedman goes so far as to claim that no Galician community possessed statutes. This remark might refer to the period before 1868 , but in many other places the author mentions facts that took place after this year; Friedman 1929: 145.

${ }^{53}$ Friedman refers to the efforts of the Jewish intelligentsia, dating back to 1848 , for the religious community to be under the jurisdiction of the local administration, Friedman 1929: 158; A. Gumplowicz's motion on separate statutes for the Jewish community in Warsaw, ANKr Mag 1808. My thanks to Dr Alicja Maślak-Maciejewska for finding and making this motion available to me.

${ }^{54}$ Statut dla Zboru izraelickiego w Krakowie 1870: 5.
} 
The material characteristics included:

Ownership of property; ownership of industrial workplaces located in the area of the congregation; possession of annuity, possession of an investment in capital, if the owners of the properties detailed under 1,2,3,4 pay a permanent tax for the congregation fund, and in the case of a permanent government tax at least in the amount of 5 Austrian gulden annually (not counting additions). ${ }^{55}$

Exclusion from elections $(\S 10)$ was determined by incapacitation, criminal convictions or implication in an investigation, or bankruptcy.

Every voter had only one voting card $(\S 12)$, and if a property had several owners, only the co-owner who had the largest share was entitled to a vote $(\S 11)$.

The members of a community in arrears with contributions or not appearing at elections were suspended from participation in elections $(\S 15)$.

To be selected as a council member, it was necessary to be a member of the congregation "who is at least 30 years old, able to read and write in Polish or German, possesses the personal attributes of a voter, and whose right to vote is not suspended" $(\S 16){ }^{56}$ First- or second-degree relatives could not be elected to the congregation council at the same time $(\S 17)$. People with an official relationship to the congregation could not be selected as senior council members, but only as congregation councillors.

Article 20 regulated the election procedure. It referred to the existence of three electoral circles constituted according to the amount of congregation contributions paid, or optionally government taxes starting from 5 Austrian gulden. The electoral circle of the highest-taxed voters also included those with the right to vote "on the basis of their scientific or artistic profession, their office or their status". ${ }^{57}$

The council had extensive competences, including changes to the congregation statute, filling the post of preacher and rabbi, the form of instructions for all officials, the regulations applying to meetings, the amount of wages and pensions, and admission and removal of officials. It also administered finances, set taxes and acquired property, granted loans and leave, established new workplaces and scrapped old ones, among other duties $(\S 47) .{ }^{58}$

Rachel Manekin notes that liberal statutes abolished the original "democratism" of council elections (in the past every homeowner had a vote) in favour of richer people (those who owned more had more influence $-\S 20) .{ }^{59}$ This preferential treatment of the wealthy guaranteed rather curious elections, because the same number of representatives were elected to each curia, but the number of voters varied: there were fewest in the first circle. The most contentious articles, in terms of interventions and appeals to the municipal authorities, were those which authorised the intelligentsia with a secular education to participate in the local government, and as an alternative census to the denominational tax also permitted government taxes in the amount of at least 5 gulden annually. As a result, "secular" individuals, who often treated religious regulations selectively, were also admitted to the community council, i.e. the corporation

\footnotetext{
${ }^{55}$ Ibid.: 5 .

${ }^{56}$ Ibid.: 7.

${ }^{57}$ Ibid.: 8.

${ }^{58}$ Ibid.: 14-16.

${ }^{59}$ Manekin 2011: 170.
} 
whose objective was to satisfy not only the religious, but also the social needs of a specific confessional group. Moreover, eligibility for election was subject not only to the religious tax, but also the state one. This theoretically permitted people who had not paid religious taxes and were potentially therefore "indifferent" to religious issues, to elect the community authorities. The criterion of secular education for deputies of the first curia meant that it could be dominated by the Jewish intelligentsia. This group had an impact on the election of an integrationist to the position of community president. The statutes of Krakow permitted the new elites which would have been overlooked by the traditional laws to participate in government.

The elections were overseen by the municipal authorities. ${ }^{60}$ The members with seats in the first curia were often municipal councillors. The integrationists could thus see themselves as intermediaries between the confessional community and the municipal one, which they of course took advantage of to pursue their own visions.

\section{Schreiber's politics}

The fact that the religious communities of the two largest cities had authorised statutes that could act as a model for further communities did not satisfy everybody. Those who were less than happy feared that the changes were a threat to their rightful positions in the community. The struggle over the form of modern statutes for the religious communities was one of the most important battles fought by the elites of those communities. ${ }^{61}$ It was lack of agreement with the liberal nature of the L'viv statutes that apparently led to the formation of Orthodox groups in Galicia. One of the most respected representatives of the local Orthodoxy was the aforementioned Cracovian rabbi Szymon Schreiber (Shimon Sofer), also one of the founders of the Machsike ha-Dat political association. $^{62}$

It seems that Schreiber held more power in Krakow than rabbis in other cities - for a long time, there was no formal religious-based body in the community with which he had to consult. ${ }^{63}$ Presumably this rabbinical autarchy was not to the taste even of the local Orthodox Jews, who wanted to have a say in administration of the community. Despite his official affiliation to Krakow, however, the base of Schreiber's support was in Eastern Galicia, where he was backed by numerous rabbis as well as the aforementioned and highly esteemed Rabbi Rokeach from Belz.

In order to come to an agreement and organise a uniform campaign, in 1878 the Progressive community councils organised a joint meeting in L'viv, ${ }^{64}$ which was criticised by Schreiber. ${ }^{65}$ Plans were made to establish an organisation, the Gemeindebund, representing

${ }^{60} \S 26$. Komisarz polityczny, Statut zboru izraelickiego 1870: 9.

61 Żbikowski 1994: 23.

${ }^{62}$ Friedman called Krakow "the main site of Orthodox Judaism", and believed that Schreiber brought the methods used in the struggle with Progressive Jews from his native Hungary; Friedman 1929: 42.

${ }^{63}$ Ibid.: 147.

${ }^{64}$ Rosenfeld 1918: 251; Friedman wrote that representatives of 25 communities took part, discussing such issues as statutes for religious communities; Friedman 1929: 143; Bałaban 1907: 33; Bałaban 1937: 24.

65 “Unser Cultuskampf in Galizien", Neuzeit 16 May 1879, no. 20: $153 \mathrm{f}$. 
all Galician communities, and a standard statute was produced for religious communities (itself modelled on the L'viv statutes). ${ }^{66}$ One resolution made at this meeting, supported by Schomer Israel, was to organise a seminary for training modern rabbis. ${ }^{67}$

In response to the Progressives' initiatives, Schreiber, together with Rokeach, organised a small meeting of supporters ${ }^{68}$ at which it was decided to call a meeting of Orthodox rabbis in 1879, which became known by the Progressive opposition as the "Belzer Synode". ${ }^{69}$ Their opponents were furious that the costs of the event would be borne by Galician communities. ${ }^{70}$

Seeking backers, Schreiber, along with other Orthodox rabbis and Machsike ha-Dat, approached the council of the L'viv community in December 1879 proposing that it join the petition to the Imperial Council and award Schreiber general power of attorney to represent their interests. ${ }^{71}$ The Progressive community council rejected this request indignantly, arguing that Merunowicz's petition lacked the essential punching power, and the Orthodox initiative was only likely to popularise it unnecessarily. The council of the L'viv community also refused the competences to undertake such an action to the rabbis themselves, as well as the "entirely bereft of such competences Machsike ha-Dat", arguing that only the councils of the most eminent communities had such authorisation. (In this case the L'viv community, where Progressives played a significant role, was probably meant.) Furthermore, the council of the L'viv community did not agree with the petition's argument that the differences between Jews in various communities were greater than those dividing Catholics and Protestants. The community council criticised Schreiber's attempts to divide the Jewish communities into Orthodox and Progressive as well as actions opposing the school obligation. The council declined to award him power of attorney to represent the interests of the L'viv community. Schreiber's initiative did however secure the support of the authorities of the Krakow community, ${ }^{72}$ which a year earlier had refused to participate in the congress of communities organised by the liberal religious community in L'viv. ${ }^{73}$ The conceited and self-important Merunowicz assigned himself a leading role in the ongoing process of consolidation of Orthodox Judaism, and ignored processes taking place within the Galician Jewry entirely. ${ }^{74}$

In 1879 Schreiber was elected to the Vienna parliament in the Kołomyja-Śniatyń-Buczacz district. ${ }^{75}$ His opponents were Progressive Jews, including the presidents of

\footnotetext{
${ }^{66}$ Rosenfeld 1918: 251; Manekin 2011: 175. Bericht über die Verhandlung des I. galizisch-jüdischen Kultusgemeindetages, Lemberg 1878.

${ }^{67}$ Bałaban 1907: 33 and Bałaban 1937: 24; Semczyszyn 2014: 291.

${ }^{68}$ Manekin 2011: 175.

69 "Kleine Chronik, Lemberg", Neuzeit 11 April 1879, no. 14: 116; Fryling 1883: 10f.

70 "Kleine Chronik. Lemberg", Neuzeit 27 June 1879, no. 26: 203.

71 "Kleine Chronik, Lemberg”, Neuzeit 9 January 1879, no. 2: 14; cf. Semczyszyn 2014: 291. Zwi Hirsch Ornstein (?-2888) was the main representative of the Lwów Talmudic Orthodox Jewry; Friedman 1929: 41; Leszczyński: Ornstein, “Zwi Hirsch”, at: http://www.biographien.ac.at/oebl/oebl_O/Ornstein_ZwiHirsch 1888.xml (Accessed: 5 April 2018).

72 Żbikowski 1995: 59.

${ }^{73}$ Ibid: 154.

${ }^{74}$ Merunowicz, in: Sprawozdanie stenograficzne z rozpraw galicyjskiego Sejmu krajowego 1882: 65.

75 “Kleine Chronik, Lemberg”, Neuzeit 18 July 1879, no. 29: 228; Semczyszyn 2014: 215.
} 
the Schomer Israel association, Dr Emil Byk and Dr Bernard Löwenstein. ${ }^{76}$ The very presence of an Orthodox rabbi in a liberal parliament was an event in itself. ${ }^{77}$ Schreiber associated himself not with the liberals, but with the conservative Polish Club, of which he was a member in 1879-1883. According to Viennese liberals, who could not forgive him for this accession, ${ }^{78}$ Schreiber was the first Jew from Galicia to join the club. ${ }^{79}$ (It is unclear why Albert Mendelsburg, who joined the Polish Club in 1873, is overlooked here $^{80}$; perhaps it was the accession of members elected in Eastern Galicia that they had in mind?) From the Orthodox rabbi's point of view, however, it is hardly surprising that he supported the Galician conservatives. ${ }^{81}$ Whereas the liberals were interested in "nationalising" the Jewish communities, i.e. subjecting them to generally binding legal norms, the conservatives and autonomists supported federalism in Galicia and the autonomy of the crown lands. Only conservatism together with federalism would make it possible to maintain/introduce wide-ranging autonomy of religious communities. The requirement to use Polish during proceedings was apparently the reason why Schreiber was not active in discussions of the Polish Club. Presumably he played more of a role "behind the scenes", where he was canvassing for support for his draft statute. So was he in this way pursuing his policy of "personal intercession"?

In 1882 Schreiber participated in an enquiry on the subject of reform of the Jewish communities, called by Minister of Education and Religions Baron Konrad v. Eybesfeld. ${ }^{83}$ There were both Orthodox and Progressive participants in the enquiry. ${ }^{84} \mathrm{Sch}-$ reiber took the floor (he was a German speaker), wishing to carry through two issues: 1) for rabbis not to be expected to have any other knowledge than Talmudic, 2) demanding the right to withdraw from a spiritual community, or to remove someone through the kahal from a community relationship (Lasker's German law). ${ }^{85}$ Schreiber therefore opposed the requirement of academic education placed by the liberals, and was also preparing the ground for the division of Jewish communities into Progressive and Orthodox ones, presenting a corresponding draft statute for religious communities modelled on the statutes of Hungarian Orthodox communities. ${ }^{86}$

76 "Kleine Chronik. Lemberg", Neuzeit 11 April 1879, no. 14: 116; Bałaban 1937: 81-97; Semczyszyn 2014: 291. Bernard Löwenstein (1821-1888), see Borzymińska, Zofia: http://www.jhi.pl/psj/Loewenstein_ Bernard (Accessed: 5 April 2018); Emil Byk (1845-1906) see Żebrowski, Rafał: http://www.jhi.pl/psj/ Byk_Emil (Accessed: 16 April 2018); Fałowski 2009: 37-53; on the rival candidate Byk, see Bloch 1922: 221-239, 276.

77 "Der Schulchan-Aruch und das Reichstagsmandat. Eine Schaalah und eine Th'schuba", Neuzeit 29 August 1879, no. 35: 273f.

78 "Rabbiner Schreiber in der Adreßendabatte des Unterhauses", Neuzeit 7 November 1879, no. 45: 353f.

${ }^{79}$ Ibid.: 354 . In 1879 Machsike Hadas also appealed to the Galician conservatives for support; Semczyszyn 2014: 286.

${ }^{80}$ Friedman 1929: 186.

81 “Unser Kulturkampf in Galizien”, Neuzeit 16 May 1878: 1f.

${ }^{82}$ Binder 2005: 55.

${ }^{83}$ Bałaban 1909: 28; Bałaban 1907: 34.

84 “Korespondencja Czasu. Wiedeń”, Czas 12 February 1888, no. 35: 1; Bałaban 1909: 28.

${ }^{85}$ Bałaban 1909: 28.

86 “Lemberg", Neuzeit 16 May 1879, no. 20: 154; Fryling 1883: 12. 
The bill was protested by the L'viv community and Schomer Israel. ${ }^{87}$ In May 1882 a protest was submitted against Schreiber's statute to the Ministry of Religions and Education, and the Progressives were successful in the elections to the L'viv kahal that were taking place at the time.

In the end, Schreiber's draft statute did not secure sufficient support, and was rejected:

The Ministry of Religions and Education has rejected Schreiber's model statute, for it accords almost unrestricted power to the rabbi and removes the community's right to independent administration of its religious and confessional relations, which the community regards as its spiritual head, its legal organ and its only representative internally as well as externally with respect to the authorities, in all religious, ceremonial and ritual affairs, regarding which the managing council will not exert any influence or require certificates of capacity. ${ }^{88}$

The proposal to divide the Jewish communities into Orthodox and Progressive therefore did not pass. According to Manekin, Schreiber departed from a traditional understanding of politics, and was the founder of modern Orthodox politics: he himself announced his participation in politics, e.g. taking part in elections, religious compulsion, and mitzvah. ${ }^{89}$ Schreiber understood that those who gained the support of the broadest possible electorate would have a chance in politics. ${ }^{90}$ He thereby opposed the hitherto binding principle whereby Jews ceded their political activity to the representatives of Progressive communities and chose a Progressive Jew as their representative. According to Schreiber, Jews should not elect Progressives, who "do not hold to any religion", but rather a Christian..$^{91}$ For this reason too, Machsike ha-Dat organised its own electoral committees and put its own candidates forward. ${ }^{92}$

Schreiber's innovation, it would appear, was mainly about using new organisational forms and media to protect the independence of Jewish communities, threatened by the actions of politicians interested in increasing administrative control over them. As we saw previously, the views of the "backward" community were disseminated through the press and at mass meetings. (It is debatable whether these meetings could be regarded as a modern form of communication, since they alluded to previously organised

${ }^{87}$ Rosenfeld 1918: 251; Bałaban 1909: 29; Bałaban 1907: 35.

88 "Korespondencya 'Nowej Reformy", $N R$ 1883, no. 68: 2. Fryling noted that Minister Florian Ziemiałkowski contributed to rejecting Schreiber's statutes; Fryling 1883: 4.

89 " [...] fights the danger of the modern world by employing that world's methods and tools, and by internalizing of them", Manekin 2011: 174, 179 (mitzvah); "Machsike Hadas was the first Jewish political association to wield religion as a political tool, a strategy that proved highly successful", Manekin, Rachel, in: https://www.academia.edu/18085069/English_Abstract_The_Jews_of_Galicia_and_the_Austrian_Constitution_The_Beginning_of_Modern_Jewish_Politics (Accessed: 5 February 2018).

${ }^{90}$ Manekin 2011: 176; "Diese galizischen Fanatiker sind weit entfernt davon, die Früchte der Zivilisation wie ihre Vorfahren vor einem halben Jahrhundert zu verschmähen. Sie wollen die politische und soziale Gleichstellung, sie appelieren an die Gewissensfreiheit, sie streben nach den Genüssen, die die Kultur bietet, aber sie scheuen die Betheiligung an der Kulturarbeit und lähmen alle Thätigkeit auf diesem Gebiete", in: "Kulturkampf in Galizien", Neuzeit 18 April 1878: 122.

${ }^{91}$ D. [Dobrzański, Jan]: “Wizyta u rabina krakowskiego”, Gazeta Narodowa 17 July 1879, no. 163: 2.

92 Semczyszyn 2014: 292; Fryling 1883: 3. Machsike repeated the strategy of the liberal and centralist Schomer Israel, which even in the 1873 campaign for the first direct elections to the State Council had formed its own electoral committee; Semczyszyn 2014: 77, 136f., 274-286. 
congresses and assemblies.) Schreiber made use of the press organ Machsike ha-Dat established by his supporters, for example to publicise a curse on Dr Filip Zucker, disallowing voting for his candidacy to the Diet:93 "Cursed be anybody who gives his vote to Zucker and similar, may divine disfavour meet him for future generations, and may his torments last longer than eternal torments". ${ }^{4}$ In the same publication, Schreiber warned Joseph Samuel Bloch (1883-1895), ${ }^{95}$ the rabbi from Floridsdorf who disputed the accusations of Jews of ritual murder, that their main accuser, the anti-Semite August Rohling, along with his Galician equivalent Teofil Merunowicz, were less harmful than Filip Zucker and the liberal deputy to the Vienna parliament Ignacy Kuranda. By making this comparison, Schreiber was probably underlining the more dangerous nature of the threats within Judaism than those coming from outside.

The ban on voting for Zucker and the order to participate in the elections proved successful. In 1883 Zucker was not elected to the regional assembly in his traditional district, the town of Brody. Schreiber thereby thwarted the prospect of participation in the assembly of one of the most effective representatives of Jews, an impassioned speaker and worthy opponent of the anti-Semite Teofil Merunowicz. Yet Schreiber's victory was short-lived, as soon afterwards Zucker entered the diet as a delegate of Brody's Chamber of Commerce. In this case, the influences of the liberal intelligentsia, which backed the election of Zucker, overcame the power of momentarily mobilised Orthodox-Hasidic forces.

Schreiber's frequently noted silence in the Vienna parliament and in the Polish club might have been caused not so much by the language requirement (although he did not know Polish, he spoke German), as by a reluctance to involve himself in general matters. After all, his priority was to implement the statute bill and division of Jewish communities, and only with this objective did he stand for election. This is demonstrated by the Krakow rabbi's aforementioned statements in the 1882 enquiry on the nonobligatory nature of secular education for rabbis, as well as the possibility of excluding inconvenient individuals through authority of the kahal from the religious community. ${ }^{96}$

Schreiber died on 26 March $1883 .{ }^{97}$ It was also at this time that anti-Semitic persecution began, concentrated around an alleged ritual murder in Tiszaeszlár. ${ }^{98}$ The Galician contribution to this discussion was the "Ritter affair", the first instalment of which came with the Rzeszów trial in $1882 .{ }^{99}$ Unfortunately, the available literature does not tell us whether Schreiber referred to the "murder". It is also unclear why the Rzeszów court approached the Vienna rabbinate for relevant opinions, rather than Schreiber,

${ }_{93}^{3}$ Manekin 2011: 178f.; "Korespondencya Nowej Reformy”, Nowa Reforma 11 February 1883, no. 33: 1-2; Semczyszyn 2014: 76, 214f. Zucker's obituary, Izraelita. Organ Stowarzyszenia „Szomer Izrael”, 28 January 1887, no. 2: 1-2. My thanks to Dr Maria Vovchko for providing me with access to the obituary.

94 "Korespondencya Nowej Reformy", Nowa Reforma 11 February 1883, no. 33: 1-2; Fryling 1883: 12-14. According to Semczyszyn, 320 rabbis signed the curse, Semczyszyn 2014: 76. On the language used by Schreiber, see Manekin 2011: 181.

${ }^{95}$ Bałaban 1936: 126. Phootograph of Bloch in: Polscy członkowie austryjackiej Izby 1892: 16.

${ }^{96}$ Bałaban 1907: 35.

97 “Kronika”, Nowa Reforma 28 March 1883, no. 70: 2.

${ }^{98}$ Kieval, Tiszaelszár, at: http://www.yivoencyclopedia.org/article.aspx/Tiszaeszlar_Blood_Libel (Accessed: 20 April 2018).

${ }^{99}$ Cieśla, Żyndul 2004: 439-451; Buchen 2012. 
who, as a deputy to the Vienna parliament and a recognised rabbinical authority, had all the requisite qualifications for issuing such a document.

In summary of Schreiber's effectiveness, we can say that he succeeded in mobilising and consolidating the Orthodox Jewry, which paved the way for their candidate to receive a seat in the Vienna parliament. He recognised the need for and usefulness of political mobilisation of broad sections of the Jewish electorate, yet he was unsuccessful in parlaying this success into achieving his own goals: his statute bill was not passed, communities were not divided into Orthodox and Progressive ones, and he was unable to limit the influence of Progressive Jews in the diet. ${ }^{100}$ Schreiber's "heir" in the Polish Club was the aforementioned rabbi of Floridsdorf, Joseph Samuel Bloch, who was elected by the Śniatyń-Kołomyja-Buczacz community. This election was in fact unlawful, since Bloch did not live in Galicia, ${ }^{101}$ but unlike Schreiber, he knew both Polish and German. The choice of Bloch satisfied the needs of both the Orthodox and the Progressive electorate. ${ }^{102}$ Could he be recognised as a symbol of the onset of a new, more conciliatory era?

Bloch's activity in the Polish Club is a subject for another researcher. I did not find any information on visits made by him to the religious community in Krakow; apparently, he only visited his electoral district and Eastern Galicia. The issues he dealt with in Krakow were in the context of conversion of Jewish girls (Mädchenraub), who ran away to convents to convert to Catholicism. ${ }^{103}$ Particularly popular in this respect was the Felician Sisters convent on Smoleńsk Street in Krakow.

Why was Schreiber so unsuccessful? His contemporary, the Austrian lawyer and specialist in administrative law Rudolf Herrmann von Herrnritt, noted that Schreiber's express desire for the state to enact appropriate legislation to recognise the differences between various factions of Jewry and indicate which "variant" is the proper one was impossible to achieve. ${ }^{104}$ The legislature did not see it as their role to interfere in community affairs, and sought to reduce such interferences to a minimum. In 1929 Philip Friedman attributed the failure to the dominant spirit of the era, which Schreiber opposed. ${ }^{105}$ If we accept these explanations, we must acknowledge that Schreiber miscalculated the prevailing political tendencies, overestimating both the interest of the secular authorities in regulating the legal situation of the Jewish communities and the punching power of his supporters (the Polish Club).

To explain Schreiber's aspirations and ideas, it will help to analyse the specific details of his proposed statute and the Progressive representatives' evaluation of the bill.

${ }^{100}$ D. [Dobrzański, Jan]: "Wizyta u rabina krakowskiego", Gazeta Narodowa 16 July 1879, no. 162: 2 and Gazeta Narodowa 17 July 1879, no. 163: 2.

${ }^{101}$ In 1879 a law was passed prohibiting foreigners as well as people born in Galicia but permanently resident outside its borders from running for election. Bloch's rival candidates were the Schomer Israel activist Dr Emil Byk and the Viennese barrister and editor of the Vienna newspaper Jüdisches Weltblatt Berggrün; Semczyszyn 2014: 205, 297. On the election see Bloch 1922: 77-80, 220-239.

${ }^{102}$ Bloch was not a candidate of all Orthodox Jews, as he was opposed by the supporters of Szymon Schreiber, e.g. his nephew Isaac Leib Sofer, the head of Machsike ha-Dat, and the tsaddik from Belz; Bloch, 1922: 282f; Manekin 2011: 179f.

${ }^{103}$ Buchen 2010: 193-214.

${ }^{104}$ Herrnritt 1905: 974.

${ }^{105}$ Friedman 1929: 208. 


\section{Schreiber's statute}

In 1882 the traditional groups organised a mass meeting of the Orthodox representatives of the L'viv communities, ${ }^{106}$ at which Schreiber presented the model statute for confessional communities in Galicia. ${ }^{107}$ During the congress, Orthodox Galician Jews were obliged to pray and fast. The Cracovian Progressive and municipal councillor Dr Jonatan Warschauer argued that Rabbi Schreiber was unqualified to undertake such an initiative, since it lay within the remit of the Imperial Council or of the Diet. ${ }^{108}$ If Warschauer acknowledged Schreiber's right to draft statutes, this was not before the Galician rabbis of "the whole Jewish world".

The leitmotifs of Schreiber's statutes were "orthodoxy", upon which the rabbi decided, and the scope of the rabbi's authority, which was considerably wider than that of the community council. According to Warschauer, Schreiber wanted to change the rabbinate into a dictatorship, and the statute surrendered communities to his mercy. A rabbi could not be removed, as he was a permanent official in perpetuity. ${ }^{109} \mathrm{He}$ did not need to possess academic education; the references of two Orthodox rabbis were sufficient. If he had previously served as a rabbi, even this was unnecessary. ${ }^{110}$ The statute accorded the rabbi extensive powers; e.g. he was not subjective to verification from the council ${ }^{111}$ and his agreement was a condition of many administrative initiatives. In order to buy and sell property and real estate, for instance, the religious community needed the authorisation of the rabbi. ${ }^{112}$ Assessors and shochtim were appointed by the rabbi and paid by the community. ${ }^{113}$ The rabbi permitted or forbade holding sermons, so censorship in the community was up to him. ${ }^{114}$

Articles 39 and 44 stipulated that participation in community elections was reserved for Jews who had belonged to the community for at least one year and were aged at least 24 , regardless of payment of contributions, since they paid indirectly by buying kosher meat. ${ }^{115}$ The statute thereby restored the original community democratism referred to by Manekin. ${ }^{116}$ Voters were not divided by curiae, thus keeping to a minimum the chances of the intelligentsia/minorities being elected. Furthermore, the statute contained

106 " $[\ldots]$ the agitation of a congress of Orthodox rabbis and miracle-workers in 1882, called to consider the ways of counteracting the intended system of control of the state authorities of the internal life of religious communities", in: Grabiec 1922: 60-104, here 66; Feldman 1907: 275.

${ }^{107}$ Schreiber 1882; Bałaban 1909: 29; Friedman 1929: 157; Rosenfeld 1918: 251.

${ }^{108}$ Warschauer, Jonatan: "W sprawie wiecu rabinów”, Nowa Reforma 8 March 1882, no. 55: 1.

$109 \S 21$, section 7: [Der Verwaltungsraths-Aussuss ist befähigt] "7. Die Cultusgemeinde-Angestellten mit Ausnahme des Rabbiners, Schächters und Vorbeters zu suspendieren, und Anträge auf deren Anstellung, Pensionierung und Entlassung beim Verwaltungsrathe zu stellen" in: Schreiber 1882: 9 (emphasis in original); Warschauer, Jonatan: "W sprawie wiecu rabinów", Nowa Reforma 9 March 1882, no. 56: 2.

${ }^{110}$ X. Abschnitt $§ 63$, Schreiber 1882: $21 \mathrm{f}$.

111 Ibid.: $21 \mathrm{f}$.

112 Abschnitt III, $\S 1$ and 5, Schreiber 1882: 6.

${ }^{113}$ X. Abschnitt $\$ 63$ f), i) $§ 64$, Schreiber 1882: 22.

${ }^{114}$ X. Abschnitt $\left.\S 63 \mathrm{~g}\right)$ : "Das Abhalten der Droschoth in der Synagoge durch fremde oder einheimische Religionsgelehrte zu veranlassen oder zu untersagen”, Schreiber 1882: 22.

${ }^{115}$ Schreiber 1882: 15; Warschauer, Jonatan: "W sprawie wiecu rabinów", Nowa Reforma 8 March 1882, no. 55 : 1 .

${ }^{116}$ Manekin 2011: 170. 
the condition that criminals, non-believers and those who had failed on a number of occasions to observe the religious regulations codified in the Schulchan Aruch be barred from voting. ${ }^{117}$ Mentioning the representatives of these various groups in one stroke elicited strong emotions, characterising Schreiber's view of the Jewish intelligentsia.

In $\S 23$ a) it was resolved that "Discourse during proceedings takes place in a dialect comprehensible and accessible to all those present". ${ }^{118}$ This can be interpreted as an attack on the recently introduced national language and the decree that the authorities deliberate in Polish and minutes be recorded in that language.

In addition, in VII, $\S 27$ it was resolved that every community should sustain a Talmud-Torah school in which boys would study for free according to the traditional canon of reading in Hebrew, the Bible, Talmud with commentaries, and poskim. ${ }^{119}$ The school was by definition Orthodox, led by a committee of community members headed by the rabbi, who also issued a certificate of completion of studies.

In 1882, in a protest against Schreiber's statute, the Progressive circles again called a mass meeting in L'viv. This began with numerous, formal and vociferous protests of - as stated with some degree of exaggeration - "hundreds of communities". ${ }^{120}$ These protests described the statute as harmful for society, alleging that it was an attack on education, the school law, the right to autonomy guaranteed by the constitutional laws and articles 89, 92 and 94 of the community law, and requested that the government, in order to organise Israelite religious communities, administer the convocation of a legal meeting of Israelite congregations. It was noted with satisfaction that also present at the protest rally against the Schreiber statute were rabbis from Buczacz, i.e. "a representation from the city which, together with Kołomyja and Śniatyń, elected Schreiber to the Imperial Council". ${ }^{121}$

It is not difficult to notice, however, that Warschauer's summary sounded rather melancholy: "The storm passed over his [Schreiber's] head without leaving a trace - for he is a giant - Pygmies will not reach his impulse and not knock him from the pedestal", and "After all, the name of Szymon Schreiber among Jews still stuck in medieval gaberdines, despite the heavy defeat suffered at the rabbis' meeting, lost nothing of its appeal". ${ }^{122}$ The Progressives realised that they only had the support of a few, whereas Schreiber could count on crowds. The pessimism of Warschauer's words is at odds with the official opinion elaborated on the request of the governor of Galicia, found by

${ }^{117}$ IX. Abschnitt $\S 40$, Schreiber 1882: 15f. Community members who had deliberately not paid the religious tax were not classified as voters.

118 § 23. A) Die Führung des Vorsitzes bei den Berathungen des Verwaltungsrathes. "Die Debatten müssen in dem, allen Anwesenden verständlichen und geläufigen Dialekte stattfinden", Schreiber 1882: 10; Warschauer Jonatan: "W sprawie wiecu rabinów”, Nowa Reforma 8 March 1882, no. 55: 1.

119 "Die Cultusgemeinde ist verpflichtet, auf ihre Kosten eine 'Talmud-Thora' Schule zu erhalten, in welcher Kinder und Jünglinge im hebräischen Lesen, in der Bibel, Talmud mit Comentarien, Poskim, unterrichtet werden. Diese Schule muß im orthodoxen Geiste geleitet werden durch eine, vom Rabbinate aus Gemeindemitgliedern zu wählende Schul-Commission mit dem Rabbiner Obmann. Die Lehrer werden vom Verwaltungsrathe dieser Kommission angestellt; die bedürfen keine andere Qualifikations-Zeugnisse, als nur der vom Rabbiner über die Kenntnisse der obbezeichteten Lehrfächer, und über ihr religiöses, moralisches vorleben $[\ldots]$ ", Schreiber 1882: 11f.

120 "Agitacye rabina Schreibera", Nowa Reforma 21 February 1883, no. 41: 1.

121 "Lwowski zjazd rabinów”, Nowa Reforma 16 March 1882, no. 62: 3.

122 "Agitacye rabina Schreibera”, Nowa Reforma 21 February 1883, no. 41: 1. 
Manekin, stating that a statute that awarded such great power to a rabbi compromised Schreiber even in the eyes of his "own" Krakow community. ${ }^{123}$ It was probably wishful thinking by the Progressive author.

\section{Further discussion of the regulation of the status of Jewish communities}

In 1882 it proved impossible to secure the passage of the bill regulating the legal status of Galician Jews. According to the Czas correspondent, however, the target appeared to be close at hand:

In the matter of Mr Merunowicz's motions, there is again hesitation in the clubs of the Assembly as to what path to take in order not to provoke the Semite question, and to make a start on the essential reform. A few days ago we received two telegrams, one from Lwów, and the other from Vienna. The first stated that the commission intended to table the report on Mr Merunowicz's motions to restrict the confessional organisations of Jews to strictly religious matters, excluding administrative and judicial issues. The telegram from Vienna also informed of the complete readiness of the preparation in this spirit of the ministry's submission for the future Imperial Council. For now, this is only a specification of the position stipulated by the principles of state legislature, and a corresponding reaction for our country would be desirable. [...] The socio-economic question, defeating by majority vote the passive population through a more active element united in solidarity. ${ }^{124}$

The statements of the conservative politician and regional assembly deputy Jan Popiel were quoted. ${ }^{125}$ In his opinion, passing an unsuitable law represented a particular threat to small towns (i.e. those where the Josephine patent still applied). Popiel was also opposed to issuing separate statutes for the 16 mid-sized and large cities and separating them from rural districts, since this would reduce the political influence of landowners. In both cases - passing new statutes regulating the legal situation of Jewish communities and new municipal statutes - it was anticipated that new activists would come to power and new political elites would be formed; it was an imminent "changing of the guard", which those in power wanted to prevent.

In his book, published in 1918, Max Rosenfeld ${ }^{126}$ mentioned that as early as 1880 , the government of Count Eduard Taaffe (1879-1893) created a draft bill organising religious communities. ${ }^{127}$ It was sent to the House of Lords, where it remained for the next few years. ${ }^{128}$ The bill assumed that religious communities would be formed

${ }^{123}$ Manekin 2011: 180.

124 [no title], Czas 11 October 1882, no. 232: 1f., here 2. This was the year in which the first Cities and Towns rally was held by the Democrats in L'viv; Szemczyszyn 2014: 56.

${ }^{125}$ Popiel, Jan, at: Kieniewicz Stefan, http://www.ipsb.nina.gov.pl/a/biografia/jan-popiel (Accessed: 18 April 2018.

${ }^{126}$ Max Rosenfeld (1884-1919), opinion journalist, activist of Poalei Zion, deputy to the Legislative Assembly and from 1918 briefly president of the Jewish community in Przemyśl.

${ }^{127}$ Rosenfeld 1918: 252.

128 “Korespondencja Czasu. Wiedeń”, Czas 12 February 1888, no. 35: 1. 
in specific territories, whose residents would automatically become members of the religious communities. The communities would have autonomy in developing their own statute and the administration and scope of the community's activity. They could elect and organise the leadership of the community, the rabbi, and the remaining functionaries. The bill clearly defined the extent of state control, trying to avoid restrictions on Jews' independence. The hope was expressed that it would not encounter opposition from the Orthodox population, and that Progressives would see it as an improvement to the current state of affairs. Although the document was almost ready, several years passed before, in 1888 during the tenth session of the House of Lords, deliberations began on regulating the status of Jewish communities. ${ }^{129}$

Joseph Samuel Bloch mentions that Minister-President Count Eduard Taaffe, in an attempt to avoid the heated discussions and indecent statements that were common in discussions on Jews, first addressed his motion to the House of Lords (on whose benches sat "ageing notables in control of their emotions"), and only later to the "unbalanced" House of Deputies. ${ }^{130}$ The house of Lords was where doubts were discussed and amendments introduced. Despite this manoeuvre, it proved impossible to avoid a partly very anti-Semitic discussion in the House of Deputies, with Karl Türk being particularly active. Türk's arguments were opposed by Dr Alois Zucker from Moravia, and a member of the Polish Circle familiar to us, Dr Joseph Samuel Bloch. The bill was also presented at the Polish Club, where it received a majority. Since the case was designated as a matter of religion, deputies were not compelled to vote along party lines. ${ }^{131}$

\section{The law defining the external legal relations between the Jewish religious community and the state of 21 March $1890^{132}$}

Herrnritt summarised the main inclinations of the bill in five points: ${ }^{133}$

1. The existence of uniform communities is permitted, without specific preference for special interests of Orthodox and Reform Jews.

129 "Die erläuternden Bemerkungen zum Regierungsentwurfe, Beilage zu den stenographischen Protokollen des A.H. X Session 1888”, No. 678, in: Herrnritt 1905: 975; "Ustawa o zborach izraelickich", Nowa Reforma 15 February 1888, no. 37: 1-2; "Die Regelung der äußeren Rechtsverhältnisse der jüdischen Religionsgenossenschaften”, I Neuzeit 30 March 1888, no. 13: 124-129, II Neuzeit 6 April 1888: 133-135, III. On the accompanying discussions see Manekin 2011: 179.

${ }^{130}$ Bloch 1922: 263.

131 “Z Koła polskiego", Nowa Reforma 11 February 1890, no. 34: 1. https://repozytorium.amu.edu.pl/ bitstream/10593/2005/1/Borecki.pdf (Accessed: February 2018). Decisions of a religious nature were not subject to party solidarity; see Binder 2005: 323; Semczyszyn 2014: 269.

132 "Ustawa o urządzeniu stosunków prawnych zewnętrznych społeczności religijnej izraelickiej z 21 marca 1890", translation proposed by Manekin 2011: 182.

${ }^{133}$ Herrnritt 1905: 975; Gesetz vom 21. März 1890, betreffend die Regelung der äusseren Rechtsverhältnisse der israelitischen Religionsgesellschaft, RGBL 57/1890; https:/www.ris.bka.gv.at/GeltendeFassung. wxe?Abfrage=Bundesnormen\&Gesetzesnummer=10009176 (Accessed: 13 February 2018); Gesetz vom 21. März 1890, Neuzeit 25 April 1890, no. 17: 161f. and Neuzeit 2 May 1890, no. 18: 171f.; Żbikowski 1995: 114f.; Dziadzio 2001: 238-243. The law entered into force on 15 April 1890. 
2. Each Israelite must belong to the community in which he had his permanent residence (ordentlicher Wohnsitz). It is not permitted to establish a superior community.

3. Within this framework, beliefs and worships may be differentiated.

4. Full requirements regarding community officials (Kultusdiener).

5. State influence on religious taxes. It is deemed to be an internal matter of the community to determine in the statute the maximum amounts of provisions. Ratification of the statute by the political authorities resulted in the communities being able to levy fees to a higher level stipulated in it. In this way, it was intended to protect the members of communes from unjustified claims.

The community was entitled to organise itself independently on the basis of the statute. The law only designated the general framework. The elections to the statutory organs in fact only constituted the area of internal functioning of the community, which could be subject to appeal from the members to the state administrative authorities. Appointment of a rabbi was regarded as an internal community matter, but he had to be accepted by the government. Selection of the statutory community bodies was also to be verified and overseen by the administration authorities. It was not permitted to perform ceremonies in a private home.

Andrzej Dziadzio notes that, following the passage of the law, only a small number of Jewish community matters were brought before the Administrative Tribunal, and these were exclusively of a fiscal nature. As a result, he argues that "the 1890 law pertinently specified the scope of their [the communities'] autonomy, allowing the state authorities to perform their control functions with full respect for their organisational independence and confessional distinctness". ${ }^{134}$

For the Krakow community, this law did not represent a milestone: according to Andrzej Żbikowski, it changed little, as the statute of the Jewish community from 1870 had been in accordance with its later provisions. ${ }^{135}$ Majer Bałaban regarded it as a posthumous success of Rabbi Schreiber that rabbis were required to demonstrate a secular education only ten years after the law came into force. ${ }^{136}$

In 1895, on the basis of the law, model statutes were also issued for Galician religious communities, ${ }^{137}$ paving the way in subsequent years for an avalanche of statutes for specific communities.

\section{The reaction: Progressive Jews, Orthodox Jews, and Merunowicz}

The conformity of the Krakow statutes with the law of 1890 is demonstrated by the fact that the Progressives could be satisfied with it. Could the same be said about the Orthodox Jewry?

Merunowicz wrote that Jewish circles were very concerned about the preparation of the bill: "rabbis' congresses, consultations of Talmudists and lawyers took place,

\footnotetext{
134 Dziadzio 2001: 243.

135 Żbikowski 1995: 114.

${ }^{136}$ Bałaban 1909: 30; Herrnritt 1905: 979.

137 Żbikowski 1995: 115; Herrnritt 1905: 979.
} 
against this background new periodicals were founded, multiple pamphlets appeared, and there was no end of petitions and deputations to Vienna". ${ }^{138}$ One of these congresses took place before the law came into effect, on 12 March in Przeworsk. ${ }^{139}$ The participants were tsaddiks from Belz, Sieniawa, Sącz, Tarnobrzeg and Rzeszów, the rabbi from Dąbrowa Tarnowska, and a representative of Machsike Ha-Dat.

Ultimately, a constructive agreement was reached.

The Orthodox elements abandoned their previous opposing position regarding the basic resolutions of the law of 21 March 1890 - National Law Register no. 57, particularly emphasised in the pursuits of the Machsike hador [sic] associations, and arrived at the conviction that the said law enables them to freely manifest their religious rituals, no further organisation of the Israelite religious communities in the country on the basis of new statutes should take place, and this action should be complete within the nearest time. ${ }^{140}$

Yet Merunowicz completely ignored the changing legal realities and criticised the law, which was still going to reinforce the Jewish influences in Galicia, and the Jews, of course, followed the Talmud... ${ }^{141}$ According to Merunowicz, everything was as before, except perhaps for a few new Jewish communities. In 1893 he called for equality between Jews and followers of other faiths.

(Translated from Polish by Ben Koschalka)

\section{BIBLIOGRAPHY}

\section{Press}

Czas (Krakow) 1879, 1880, 1882, 1888, 1890.

Reforma (Krakow) 1882.

Nowa Reforma (Krakow) 1883, 1888, 1890.

Neue Freie Presse (Vienna) 1890.

Neuzeit (Vienna) 1879, 1880, 1882, 1890.

\section{Primary literature}

Bericht über die Verhandlung des I. galizisch-jüdischen Kultusgemeindetages, (1878), Lemberg. Gesetz vom 21. März 1890, betreffend die Regelung der äusseren Rechtsverhältnisse der israelitischen Religionsgesellschaft, RGBL 57/1890; https://www.ris.bka.gv.at/GeltendeFassung.wxe?Abfrage $=$ Bundesnormen $\&$ Gesetzesnummer=10009176 (Accessed: 13 February 2018).

${ }^{138}$ Merunowicz 1893: 85.

139 “Kleine Chronik, Przemorsk" [sic], Neuzeit 21 March 1890, no. 12: 113f. Yehoshua Rokeach (18251894); Jesechiel Sharga Halberstam (1815-1898), Shinewer Rav (1813-1898); Baruch Halberstam from Gorlice (1829-1906); Jehoshua Horowitz (1848-1912). I could not identify Luzerl; the Rzeszów rabbi at this time was Yehoshua Heschel or Lewin.

${ }^{140}$ Reskrypt wysokiego c.k. Namiestnictwa z dn. 8. Listopada 1897, ANKr Kr 7055.

${ }^{141}$ Merunowicz 1893: 84. 
Herrnitt von, H.R. (1905²), Juden: B. Israelitische Kultusangelegenheiten, in: E. Mischler, J. Ulbrich, Österreichisches Staatswörterbuch. Handbuch des gesamten österreichischen öffentlichen Rechtes, Wien, vol. 2: 974-981.

Kasparek, J.R. (1868), Zbiór ustaw administracyjnych w Królestwie Galicyi i Lodomeryi z Wielkim Księstwem Krakowskim obowiazujacych, 1868, vol. 1: 97-112.

Kasparek, J.R. (1873), Zbiór ustaw administracyjnych w Królestwie Galicyi $i$ w Lodomeryi z Wielkim Księstwem Krakowskim obowiazujących do użytku c.k. władz rządowych $i$ władz autonomicznych, Kraków, vol. III: 1589-1590.

Kasparek, J.R. (1884), Zbiór ustaw i rozporządzeń administracyjnych w Królestwie Galicyi i Lodomeryi z Wielkim Księstwem Krakowskim obowiazujących z wyciagiem orzeczeń c.k. Trybunatu administracyjnego, Kraków, vol. 1: 47-49.

Reskrypt wysokiego c.k. Namiestnictwa z dn. 8. Listopada 1897, ANKr Kr 7055.

Schreiber, S. et consorten: Statuten-Entwurf für die israelitischen Cultusgemeinden in Galizien verfasst von Rabbiner Schreiber \& consorten vorgelegt der Lemberger Rabbiner-Versammlung, (1882), Lemberg.

"Sprawozdanie stenograficzne z rozpraw galicyjskiego Sejmu krajowego 6. Posiedzenie, 5. Sesyi, IV Periodu Sejmu galicyjskiego z dnia 14. Września 1882", at: https://jbc.bj.uj.edu.pl/dlibra/publication/8722/edition/4471/content?ref=desc (Accessed: 20 April 2018).

Statut dla Zboru izraelickiego w Krakowie / Statut der israelitischen Cultur-Gemeinde in Krakau, (1870) Kraków.

Wniosek A. Gumplowicza w sprawie statutu oddzielnego dla gminy żydowskiej w Krakowie, ANKr Mag 1808.

Zuker, F. (1882), Mowa posta Dra Filipa Zukra wygloszona w sprawie uregulowania prawnych stosunków ludności izraelickiej na posiedzeniu Sejmu krajowego z dnia 10. Października 1882, Lwów.

\section{Secondary literature}

Aleksiun, N., Szomer Israel, at: http://www.jhi.pl/psj/Szomer_(Schomer)_Israel (Accessed: 5 April 2018).

Assaf, D., Belz Hasidic Dynasty, at: http://www.yivoencyclopedia.org/article.aspx/Belz_Hasidic_Dynasty (Accessed: 5 April 2018).

Bałaban, M. (1907), Historya projektu szkoły rabinów i nauki religii mojż. na ziemiach polskich, Lwów.

Bałaban, M. (1909), Żydzi w Austryi za panowania cesarza Franciszka Józefa I. ze szczególnym uwzględnieniem Galicyi, 1848-1908, Lwów, at: http://rcin.org.pl/Content/5953/WA248_5492_ F-21-773_balaban-zydzi-o.pdf (Accessed: 19 February 2018).

Bałaban, M. (1916), Dzieje Żydów w Galicyi i w Rzeczypospolitej krakowskiej 1772-1868, Lwów (reprint 1988).

Bałaban, M. (1936), Bloch Józef (1850-1923), in: Polski Stownik Biograficzny, vol. 2, ed. W. Konopczyński [et al.], Kraków.

Bałaban, M. (1937), Historia lwowskiej synagogi postępowej, Lwów.

Binder, H. (2005), Galizien in Wien. Parteien, Wahlen, Fraktionen und Abgeordnete im Übergang zur Massenpolitik, Wien.

Bloch, J. (1922), Erinnerungen aus meinem Leben, Wien/Leipzig, at: https://archive.org/details/erinnerungenausm00blocuoft (Accessed: 17 April 2018).

Borzymińska, Z. Löwenstein Bernard, at: http://www.jhi.pl/psj/Loewenstein_Bernard (Accessed: 5 April 2018).

Buchen, T. (2010), „Herkules im antisemitischen Augiasstall“ - Joseph Samuel Bloch und Galizien in der Reaktion auf Antisemitismus in der Habsburger Monarchie, in: U. Wyrwa (Hrsg.), Einspruch und Abwehr: Die Reaktion des europäischen Judentums auf die Entstehung des Antisemitismus (1879-1914), Frankfurt: 193-214. 
Buchen, T. (2012), Antisemitismus in Galizien: Agitation, Gewalt und Politik gegen Juden in der Habsburgermonarchie um 1900, Berlin.

Cieśla, M., Żyndul, J. (2004), Sprawa Ritterów. Aktualizacja legendy mordu rytualnego w Galicji końca XIX wieku, in: G. Borkowska, M. Rudkowska (eds.), Kwestia żydowska w XIX wieku. Spory o tożsamość Polaków, Warszawa: 439-451.

Dziadzio, A. (2001), Monarchia konstytucyjna w Austrii (1867-1914): Władza - obywatel-prawo, Kraków.

Fałowski, J. (2009), Żydzi w parlamencie wiedeńskim - z działalności poselskiej Emila Byka (18451906), Państwo i Społeczeństwo: pótrocznik Krakowskiej Wyższej Szkoły im. Andrzeja Frycza Modrzewskiego, vol. 9, no. 1.

Feldman, W. (1894), Asymilatorzy, syjoniści i polacy, Z powodu przełomu w stosunkach żydowskich w Galicyi, Lwów.

Feldman, W. (1907), Stronnictwa i programy polityczne w Galicyi 1846-1906, Kraków, vol. 2.

Friedman, P. (1929), Die galizischen Juden im Kampfe um ihre Gleichberechtigung (1848-1868), Frankfurt am Main.

Fryling, Z. (1883), Klątwa galicyjskich rabinów i cudotwórców, Lwów.

Grabiec, J. (1922), Wilhelm Feldman, jako publicysta i działacz społeczny, in: Pamięci Wilhelma Feldmana, Kraków: 60-104.

Kieniewicz, S., Popiel, Jan, at: http://www.ipsb.nina.gov.pl/a/biografia/jan-popiel (Accessed: 18 April 2018).

Leszczyński, J., Ornstein, Zwi-Hirsch, at: http://www.biographien.ac.at/oebl/oebl_O/Ornstein_ZwiHirsch_1888.xml (Accessed: 5 April 2018).

Kieval, H., Tiszaelszár, at: http://www.yivoencyclopedia.org/article.aspx/Tiszaeszlar_Blood_Libel (Accessed: 20 April 2018).

Lewandowska, D. (1995), Gmina wyznania mojżeszowego w Galicji Wschodniej, in: Żydowskie gminy wyznaniowe, Wrocław, vol. 1: 63-76.

Manekin, R. (2011), Orthodox Jewry in Kraków at the Turn of the Twentieth Century, Polin. Studies in Polish Jewry 23: 165-198.

Manekin, R., Makhzikey ha-Das, at: http://www.yivoencyclopedia.org/article.aspx/Makhzikey_haDas (Accessed: 1 February 2018).

Manekin, R., The Jews of Galicia and the Austrian Constitution. The Beginning of Modern Jewish Politics (abstract), at: https://www.academia.edu/18085069/ (Accessed: 5 February 2018).

Merunowicz, T. (1876), Wewnętrzne sprawy Galicyi, Lwów.

Merunowicz, T. (1879), Żydzi. Studyum społeczne, Lwów.

Merunowicz, T. (1893), Żydowscy radykaliści, Lwów.

Moszyński, M. (2017), Antysemityzm w Królestwie Polskim. Narodziny nowoczesnej ideologii antyżydowskiej (1864-1914), Poznań.

Pacholkiv, S. (2014), Galizische Judengemeinden unter Maria Theresa und Joseph II, at: http://apcz. umk.pl/czasopisma/index.php/BPMH/article/viewFile/4418/4216 (Accessed: 18 April 2018).

Polscy członkowie austryjackiej Izby panów i członkowie Koła polskiego w Wiedniu: album ofiarowane przez Koło polskie w Wiedniu JE. Prezesowi Apolinaremu Jaworskiemu (1892), Kraków.

Rosenfeld, M. (1918), Die polnische Judenfrage. Problem und Lösung, Wien.

Semczyszyn, M. (2014), Galicyjskie wybory. Działalność Centralnego Komitetu Wyborczego w Galicji Wschodniej w latach 1867-1906, Warszawa.

Zdrada, J., Merunowicz, Teofil, at: http://www.ipsb.nina.gov.pl/a/biografia/teofil-merunowicz (Accessed: 20 April 2018).

Żbikowski, A. (1994), Ideologia antysemicka 1848-1914. Wybór tekstów źródłowych, Warszawa.

Żbikowski, A. (1995), Żydzi krakowscy i ich gmina w latach 1869-1919, Warszawa.

Żebrowski, R., Byk, Emil, at: http://www.jhi.pl/psj/Byk_Emil (Accessed: 16 April 2018). 


\section{Internet sources}

http://www.jhi.pl/psj

http://www.yivoencyclopedia.org

http://rcin.org.pl

https://archive.org

https://www.ris.bka.gv.at

http://www.biographien.ac.at

http://www.ipsb.nina.gov.pl/a/biografia

http://apcz.umk.pl/czasopisma

http://www.jewishvirtuallibrary.org 